\title{
THE INCREASE OF ECOLOGICAL SAFETY OF IRRIGATED LANDS USE
}

\section{Dymov O. M.}

\section{INTRODUCTION}

The importance of irrigated melioration for Southern region of Ukraine is connected not only with natural and climatic conditions, but also with a number of socio-economic factors, namely: the presence of a powerful water-meliorative complex, increasing demand for agricultural products and long-term training of high-qualified specialists in this field.

The State Agency of Water Resources of Ukraine for the prevention of accidents, disasters, emergencies and reaction on them has the approved list of potentially dangerous objects, which counts 231 objects, which are on the balance of water economy organizations. All these objects do not constitute a single set of structures designed to provide reliable protection against weather and technogenic risks. Besides, a large number of them, due to the lack of operating costs, every year loses reliability and creates the risk of emergencies, including those that occur as a result of possible hydrodynamic accidents on the objects of water economy and hydrotechnical constructions.

A significant number of the objects of water economy have been constructed on the territory of the South of Ukraine, which amplify the hydrodynamic and environmental hazards in the region: the Main Kakhovka Canal and Hydroelectric Power Station, the cascade of reservoirs on the Dnipro River. The total bulk of cascade reservoirs is 43.7 billion $\mathrm{m}^{3}$, the useful project bulk is 18.7 billion $\mathrm{m}^{3}$, but today the efficient bulk of reservoirs is 7.7 billion $\mathrm{m}^{3}$. On the territory of Kherson region 426.8 thousand ha of irrigation systems (IS) were built, including: Kakhovka IS 243.1 thousand ha (57\%), Krasnoznamensk IS 102.0 thousand ha (24\%), Ingulets IS 18.2 thousand ha (4\%), native irrigation systems 42.3 thousand ha (10\%), local IS 21.2 thousand hectares $(5 \%)$. 


\section{Ecological safety of the agrarian sector of the economy in the zone of irrigation: theoretical and practical aspects}

Environmental safety in the Law of Ukraine "On Environmental Protection" is interpreted as a state of the environment, which ensures the prevention of environmental degradation and the occurrence of danger to human health. Extrapolated to agriculture, ecological safety can be understood as the state of the objects of the agrosphere when they and their products are not a source of safety threats to the population and do not have a negative impact on the environment.

The aggravation of the ecological situation in the agrarian sector and other sectors of the economy of Ukraine, the growth of anthropogenic loads on the environment, the irrational use of nature require the formation of fundamentally new concepts of economic development.

A number of scientists consider that ${ }^{2,3,4,5}$ environmental safety is uncertain, due to the lack of knowledge about the sustainability of ecosystems and the consequences of their disruption. It is impossible to achieve an absolute balance between society and the environment, since unpredictable types of crisis socio-ecological-economic situations always arise. Therefore, the main point of environmental safety in the agrarian sector is in reduction of the anthropogenic impact on the agro-ecosystem, which will ensure normal human life.

At different stages of social development, the concept of safety had little difference in interpretation. The development of safety theory can be divided into several main stages. At the first of them, the concept of safety was limited to the physical protection of man from

1 Закон України "Про охорону навколишнього природного середовища" [Електронний ресурс]. Режим доступу: http://zakon.rada.gov.ua

2 Качинський А. Б. Екологічна безпека України: системний аналіз перспектив покращення : монографія. К.: НІСД, 2001. 311 с.

3 Карпіщенко О. І., Ксенофонтова М. М. Агроекосистеми: проблеми стійкого розвитку : монографія. Суми: ВАТ “Сумська обласна типографія вид-во “Козацький вал", 2004. 185 с.

4 Косякова И. В. Организационно-экономические основы экологической деятельности промышленных предприятий : монография. М.: Компания Спутник+, 2006. 316 с.

5 Шевчук В. Я., Саталкін Ю. М., Білявський Г. О. та ін. Екологічне управління : підручник. К.: Либідь, 2004. 432 с. 
the influence of external natural factors and threats of the animal world. At the next stage, the need for social security appeared. Further, the concept of safety obtains technogenic expression. And finally, the modern stage, which, in addition to the pointed out features, includes another, new feature - ecological ${ }^{6}$.

Famous ecologist M.F. Reimers defines environmental safety as a set of actions, conditions and processes that do not directly or indirectly cause vital losses to the environment, to man as an individual and to society ${ }^{7}$.

E.G. Degodiuk, S.E. Degodiuk emphasize that in modern society, environmental safety prevails over all other types of safety, because most of the disturbances in the environmental sphere are caused by technogenic intervention of mankind in the nature with the gradual and irreversible transformation of the biosphere into the techno sphere ${ }^{8}$.

Agrarian production on irrigated lands involves the use of environmentally insecure substances. Thus, the use of increased doses of mineral fertilizers causes an increase in the concentration of nitrogen and phosphorus in aquatic ecosystems, which in its turn, increases the intensity of processes such as algae growth, stream slowing down, degradation of river ecosystems. Environmental pollutants also include pesticides.

Not less important factor of the effect of irrigated agriculture on agro-ecosystems is irrigation machines and mechanisms used in the production process. Thus, the result of their activity is soil overcompaction, and with the use of DDA-100MA irrigation machines pollution of lands, water resources and atmospheric air with fuel materials. As a result, dangerous substances get into the human's body through food chains, damaging the health. It is possible to solve this problem through a complex approach, which provides for the modernization of fixed assets, taking steps to reduce the pressure of

6 Фирсов И. В. Методологические основы практического управления в системе обеспечения экономической безопасности. Экономика u предпринимательство. 2014. № 1. Ч. 2 (42-2). С. 123-126.

${ }^{7}$ Реймерс Н. Ф. Экология (теория, законы, правила, принципы и гипотезы). М., 1994. С. 297-316.

8 Дегодюк Е. Г., Дегодюк С. Е. Еколого-техногенна безпека України : монографія. К.: ЕКМО, 2006. 306 с. 
machinery on soils and reduce the number of passages of this machinery over the land ${ }^{9}$.

To restore and expand the areas of irrigation, it is necessary to solve environmental and ameliorative problems in the zone of irrigation, to determine the current technological capabilities of irrigation systems and hydraulic constructions, to conduct ecological and ameliorative assessment of agricultural lands, to develop directions and stages of irrigation systems modernization, to provide integrated water resources management, to specialize irrigation systems and crop irrigation regimes to the climate changes, to increase quality and fertility indexes of the irrigated soil, to introduce innovative ways of irrigation, to improve the system of land ownership and land use, and the institutional support system to ensure efficient water economy management. In this way, to create conditions for sustainable socioeconomic development of rural areas.

One of the most important aspects in the field of environmental safety is the formation of an institutional environment, which is understood as a set of system components that provide environmental safety ${ }^{10,11}$. In other words, the institutional approach involves differentiating between the subjects of functioning and powers at the different levels of environmental safety.

The most powerful water-ameliorative complex in Ukraine is located in Kherson region with an area of irrigated land of 426.8 thousand ha, of which 312 thousand ha is actually irrigated recently, and therefore it is the most typical in the country in terms of irrigation development and conduction of agriculture on the irrigated lands. On the territory of the region there are elements of ecological network, which are of national importance, so the formation of nature protection territories of the state, which would represent all the natural resources,

${ }^{9}$ Фурдичко О. І. Агроекологія : монографія. К.: Аграрна наука, 2014. 400 с.

10 Муравых А. И. Теоретические основы управления экологической безопасностью : монография. М.: КОМЭК, 2008. 296 с.

11 Чудовська В. А. Інституційне забезпечення органічного виробництва в сільському господарстві / Матеріали доп. міжнар. наук.-практ. конф. “Економічні проблеми сталого розвитку” (м. Суми, 3-5 квітня 2012 р.). Суми: СумДУ, 2012. T. 1. С. $190-191$. 
is an integral part of the state policy in the field of environmental protection and preservation.

92.5 thousand ha (62.4 thousand ha - vertical and 30.1 thousand ha - horizontal drainage) and 106 settlements are protected against flood by the drainage systems built in the region. Areas with groundwater levels less than 2 meters in the zone of the influence of the drainage systems form 15.2 thousand ha. Partially flooded territory in 58 inhabited localities is provided with drainage systems.

Since the mid-1990s, the dramatic reduction in the area of actual irrigation has been accompanied by the following processes and phenomena: a significant deterioration of the technical condition of the irrigation systems (IS); insufficient quantity and unsatisfactory updating of the park of irrigation technique; disturbance of technological integrity of the IS; disturbance of the structure of croplands, technologies of crops cultivation, low level of resource support of cultivation technologies; unsatisfactory ecological reclamation (EC) of irrigated lands; insufficient level of budget financing for the maintenance of state water-ameliorative systems and natural conservation measures; insufficient implementation of innovative technologies of conduction of agriculture at the irrigated lands ${ }^{12}$.

The deterioration of the technical condition of the existing IS, especially their inward part, is a consequence of a significant reduction in budget financing and lack of own funds from land users. The results of the research show that in the structure of croplands on the irrigated lands there is a infringement of the optimal ratio of crops, mainly due to a critical decrease in the percentage of forage crops and an increase in the proportion of industrial crops in crop rotation, which does not meet state standards. Industrial crops are relatively highly profitable, so they are often grown on unreasonably large areas, especially in the case of sunflower. Excessive share of sunflower in the structure of the cropland leads to the depletion and decrease of soil fertility, which negatively affects the yield of the next 2-3 crops. In this regard, irrigated crop rotations should be optimized in the crop area of

12 Ромащенко М. І., Балюк С. А. Зрошення земель в Україні. Стан та шляхи поліпшення. К.: Світ, 2000. 114 с. 
sunflower, replacing it with other crops, for example soybean. Saturation with this crop in crop rotations can also be no more than $20-25 \%$. Reduction of industrial crops' areas can be achieved by increasing the share of cereals to optimum crop rotation limits (up to $40-82 \%$ ) at the expense of winter wheat and corn.

In the conditions of constant use of water resources, with their limited reserves and uneven distribution, a scientifically based system of water management and irrigated agriculture is required, which would ensure optimal distribution of water resources by naturalgeographical zones and industries of the economy, reproduction, protection and integrated use of water as well as a rational management system for the water economy complex.

The current level of fertilizer application in agriculture of Kherson region, as well as in other regions of Ukraine, does not meet the requirements of modern agriculture. The extended reproduction of soil fertility are not guaranteed, and even the nutrients supply of those nutritive elements are not restored, which were used by crops for the yield formation. The required amounts of them are used by plants from the nutrient supply of soils, impoverishing the latter (Fig. 1). Because of the lack of fertilizers and their unbalanced use, the need for mineral components of the soil increases each year. Thus, in 2016-2017, it reached $112.6-115.0 \mathrm{~kg} / \mathrm{ha}$. At the same time, a significant share of the deficit (35-40\% of this amount) belongs to nitrogen.

Organic fertilizers play an extremely important role in preserving, restoring and increasing soil fertility. However, the situation with the use of the latter in Kherson region leaves much to be desired. The number of them per 1 ha during the period of 1990-2015 decreased by 64 times, and the share of the fertilized with them area - by 40 times. This situation is a consequence of the decrease in the number of cattle in enterprises. This significantly increases the cost production of crops that require the uptook nutrients replacement in the soil. Therefore, one of the conditions for improving this situation is the development of animal husbandry and the increase of livestock in all categories of agricultural enterprises. 


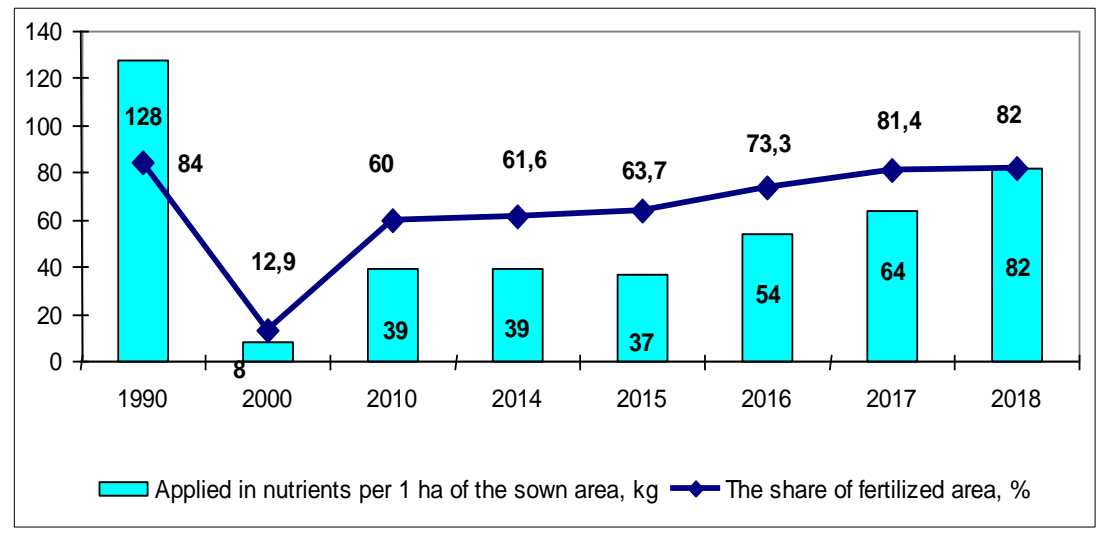

Fig. 1. Application of mineral fertilizers to the soil in agricultural enterprises of Kherson region

Source: formed by the author with accordance to the data of statistical bulletin ${ }^{13}$

Under the influence of irrigation, the ion-salt composition of the water extract of the soil changes. Prolonged irrigation with waters of high mineralization leads to the accumulation of easily soluble salts in the soil solution. Similar to the increase in the total salt content, the amount of toxic salts also increases: in the arable layer by 1.4-1.7, and in the meter layer by 1.3 times. Accordingly, the calcium content in the soil solution of the irrigated soils decreased by $0.07 \mathrm{mEq} / 100 \mathrm{~g}$ in the arable layer and by $0.09-0.13 \mathrm{mEq} / 100 \mathrm{~g}-$ in the meter layer. This leads to a narrowing of the ratio of water-soluble calcium to sodium in the arable layer from 1.7 to $0.6-0.7$ units, and in the meter layer - from 1.1 to $0.5-0.6$ units, indicating an increase in the intensity of solonetz process. The application of mineral fertilizers does not significantly affect the chemistry of the soil solution salinization of the meter layer of soil, compared to the variant without fertilizers.

In the conditions of dry Steppe climate, close groundwater laying, irrigation with highly mineralized waters, the processes of secondary

${ }^{13}$ Про внесення мінеральних, органічних добрив, гіпсування та вапнування грунтів під урожай 2010-2017 року в сільськогосподарських підприємствах Херсонської області: Статистичний бюлетень / Відп. за випуск Побрус С. В. Херсон: Головне управління статистики у Херсонській області, 2019. 48 с 
salinization and alkalization begin to occur in the soils, and the soils are subjected to wind and water erosion, etc. (Table 1).

Table 1

Areas of degraded and low-productive arable lands

in Kherson region, thousand ha

\begin{tabular}{|l|c|c|c|c|c|c|c|}
\hline \multirow{1}{*}{ Lands } & \multicolumn{7}{|c|}{ Years } \\
\cline { 2 - 8 } & 2010 & 2011 & 2012 & 2013 & 2014 & 2015 & 2016 \\
\hline $\begin{array}{l}\text { Agricultural } \\
\text { lands }\end{array}$ & 1970.7 & 1969.5 & 1969.5 & 1968.4 & 1969.0 & 1969.0 & 1969.0 \\
\hline $\begin{array}{l}\text { Including } \\
\text { arable land }\end{array}$ & 1777.2 & 1776.8 & 1776.8 & 1776.8 & 1777.9 & 1777.9 & 1777.9 \\
\hline $\begin{array}{l}\text { Among them: } \\
\text { deflation- } \\
\text { dangerous }\end{array}$ & 1689.3 & 1689.3 & 1689.3 & 1689.3 & 1689.3 & 1689.3 & 1689.3 \\
\hline saline & 590.6 & 599.6 & 599.6 & 599.6 & 599.6 & 599.6 & 599.6 \\
\hline eroded & 441.9 & 441.9 & 441.9 & 441.9 & 441.9 & 442.0 & 442.0 \\
\hline
\end{tabular}

Source: by the data of Kherson Department of Ecology and Natural Resources of the Regional State Administration

The high content of salts in soil solution and soil-absorbing complex causes a number of negative soil properties. They have an unfavorable agronomic structure, often over crust after rains, and in the post-germination period of crops there is crust formed on the surface. Too little volumes of annual soil reclamation cause an increase in the areas of saline, alkaline lands and solonetz.

Chemical amelioration of soils has been carried out in the past at state expenses and, although was cost-consumptive, has had the expected returns. Unfortunately, the measures provided for the implementation by the Law of Ukraine "On Land Reclamation", target and interstate land reclamation programs are not always implemented in the full size, mainly due to the lack of funds. In case of annual need for the gypsuming of alkaline soils in the area of 75 thousand ha, chemical amelioration is carried out on the territories,

14 Закон України “Про меліорацію земель” / Відомості Верховної ради України. 2000. № 11. С. 90. 
which form just about $2.4 \%$ of the required one. This is confirmed by the data on the bulks of chemical ameliorants used in Kherson region (Table 2).

Table 2

\begin{tabular}{|c|c|c|c|c|c|c|c|c|}
\hline Measure & \multicolumn{7}{|c|}{ Years } \\
\cline { 2 - 9 } & 2010 & 2011 & 2012 & 2013 & 2014 & 2015 & 2016 & 2017 \\
\hline $\begin{array}{c}\text { Soils } \\
\text { gypsumed, } \\
\text { thousand ha }\end{array}$ & 1.8 & 3.8 & 1.3 & 1.4 & 2.8 & 3.0 & 5.3 & 5.6 \\
\hline $\begin{array}{c}\text { Gypsum and } \\
\text { gyspseous } \\
\text { rocks, } \\
\text { thousand tons }\end{array}$ & 8.6 & 7.9 & 3.4 & 3.9 & 8.5 & 9.0 & 15.95 & 24.2 \\
\hline
\end{tabular}

Source: formed by the data of Statistical bulletin

During the years of transformation of land relations in Ukraine, no ecologically-balanced land use was formed. Imperfect reform practices have deepened the ecological imbalance of the land fund, led to a decrease in the efficiency of irrigated land use, the ability to natural restoration of fertility of soils.

\section{Ranking of agricultural enterprises by the level of ecological safety and directions of the improvement of environmentally safe use of the irrigated soils}

The difficulty of selection and substantiation of the criteria for environmental safety assessment in the field of irrigated agriculture is in the considerable variety of indexes that characterize the condition of the natural and anthropogenic environment, as well as their diversity, which virtually eliminates the possibility of a single quantitative measure of comparison and assessment.

An important element of the information and analytical component of the implementation of the environmental safety strategy in the agrarian sector is a system of criteria and indexes that provide an 
assessment of environmentally-oriented development, quantification of the level of environmental safety and ranking of its species ${ }^{15}$.

During the scientific research, we performed diagnostics of the level of ecological safety of 471 agricultural enterprises and farms in Kherson region that conduct agriculture on irrigated lands (Table 3).

Table 3

Environmental safety level of agricultural enterprises in Kherson region that perform agriculture on irrigated lands, 2017

\begin{tabular}{|l|c|c|}
\hline $\begin{array}{c}\text { Environmental safety } \\
\text { level }\end{array}$ & $\begin{array}{c}\text { The number of agricultural } \\
\text { enterprises, pc. }\end{array}$ & Share, $\%$ \\
\hline Stable & 261 & 56 \\
\hline Unsatisfactory & 135 & 29 \\
\hline Crisis & 70 & 14 \\
\hline Critical & 5 & 1 \\
\hline Total & 471 & 100 \\
\hline
\end{tabular}

The results of the analysis show that $56 \%$ of the surveyed enterprises of Kherson region, which conduct irrigated agriculture, have a stable level of environmental safety and do not create any danger to the environment and humans through their activities, 29 - meet the requirements of unsatisfactory level, 14 - at the crisis level, and $1 \%$ are in the critical level zone.

Sustainable development of the agrarian sector of the zone of irrigation, stable economic growth of agricultural production, which does not lead to significant degradation of the environment, can be ensured by developing an institutional mechanism for ensuring environmental safety in irrigated agriculture. The tools of this mechanism can be conditionally grouped into the following blocks: environmental standards, environmental control, financial and economic instruments and environmental culture.

15 Індикатори стану екологічної безпеки держави: [Електронний ресурс] / Аналітична записка. Національний інститут стратегічних досліджень. Режим доступу: http://www.niss.gov.ua/articles/993/ 
Taking into account the existing forms of the appearing threats to ecological safety, we have determined the list of indicators by the criteria and constituent elements of ecological safety in the field of irrigated agriculture. Indexes characterize the conditions of irrigated lands, the likelihood of risks, which have a negative effect on the level of environmental safety (Fig. 2).

We have analyzed and determined the level of environmental safety for specific agricultural enterprises. To be more objective, we excluded from the indexes that are on the list of integrative index of ecological safety in the agrarian sector the indexes that characterize the criterion of human health and normal vital functions. In our opinion, the complex of the indexes, which characterize the level of environmental safety of an agricultural enterprise, consists of nine indicators (Table 4).

The intensification of irrigated agriculture, the increase in levels of anthropogenic loads on agricultural landscapes require a systematic approach to the problems of the use of irrigated land, which must be solved on the basis of the data of environmental monitoring, which allows identifying changes, carrying out a comprehensive assessment, prevention and elimination of the negative effects of degradation processes. The orientation, periodicity and speed of soil conversion under the influence of irrigation are determined by: initial soil condition, quality of irrigation water, level of natural drainage of the territory, irrigation technology and intensity of use of irrigated lands. Environmental monitoring of irrigated lands gives a systematic assessment of the ecological situation, shows the degree of vulnerability of the territories to negative phenomena and the possibility of developing proposals to eliminate and prevent degradation processes. Various scenarios of ecologically oriented land use systems have been developed to evaluate the further efficient use of irrigated lands, taking into account the ecological status of these lands (Fig. 3).

The results of the investigations showed that the improvement of the existing system of monitoring management is possible through the formation and implementation of a unified state environmental monitoring system (USEMS), which will be regional by its nature and will define the territorial subsystems of USEMS in the formation of the regional environmental monitoring system. 
Table 4

Indexes of ecological safety of an agricultural enterprise and their threshold values

\begin{tabular}{|l|c|c|c|}
\hline \multicolumn{1}{|c|}{ The name of an indicator } & $\begin{array}{c}\text { Threshold } \\
\text { values }\end{array}$ & $\begin{array}{c}\text { The criterium } \\
\text { of the optimum } \\
\text { of threshold } \\
\text { indicator }\end{array}$ & $\begin{array}{c}\text { Value } \\
\text { of weighing } \\
\text { coefficient }\end{array}$ \\
\hline $\begin{array}{l}\text { Ecological and agro- } \\
\text { chemical evaluation, points }\end{array}$ & 100 & $\max$ & 0.10 \\
\hline $\begin{array}{l}\text { Coefficient of ecological } \\
\text { stability of the area, units }\end{array}$ & 0.51 & $\max$ & 0.11 \\
\hline Land erosion,\% & 10 & $\min$ & 0.16 \\
\hline $\begin{array}{l}\text { Pesticide load, kg/ha of } \\
\text { active substances per year }\end{array}$ & 1.2 & $\min$ & 0.11 \\
\hline $\begin{array}{l}\text { Chemical load, kg/ha of } \\
\text { active substances per year }\end{array}$ & 90 & $\min$ & 0.11 \\
\hline $\begin{array}{l}\text { Dynamics of the humus } \\
\text { content, \% }\end{array}$ & 100 & $\max$ & 0.15 \\
\hline $\begin{array}{l}\text { The level of use of } \\
\text { substantiated rates of } \\
\text { organic fertilizers, } \%\end{array}$ & 100 & $\max$ & 0.08 \\
\hline $\begin{array}{l}\text { The area of polluted with } \\
\text { ribonuclear agricultural } \\
\text { lands, } \%\end{array}$ & 1 & $\min$ & 0.07 \\
\hline $\begin{array}{l}\text { The share of the compo- } \\
\text { nents of ecological network } \\
\text { in the total structure of } \\
\text { agricultural lands, } \%\end{array}$ & 40 & $\max$ & 0.10 \\
\hline
\end{tabular}

In order to improve the environmental safety of irrigated agricultural land use on the basis of the USEMS of irrigated land, scenarios of ecologically oriented land use systems in the irrigation zone should be developed and scientifically proved, namely: the use of irrigated land for the cultivation of environmentally safe products; the use of irrigated land in generally accepted regional systems of irrigated agriculture; exclusion of land from irrigation by conservation of separate arrays of irrigated lands that are in degraded condition. 
Evolution of the irrigated lands

Irrigation with the water of I class, automorphic and sub-automorphic conditions

\begin{tabular}{|c|}
\hline $\begin{array}{c}\text { High culture } \\
\text { of agriculture }\end{array}$ \\
\hline
\end{tabular}

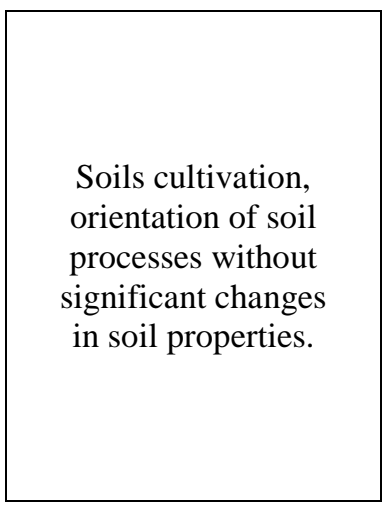

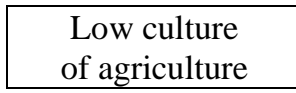

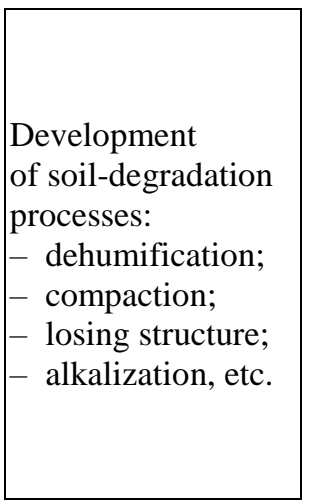

Irrigation with the waters of II and III classes, hygromorphic and sub-hygromorphic conditions

Development of degradation processes:

- rise of the groundwater level, flooding, swamping; - secondary salinization and alkalization of soils; - deterioration of agrophysical properties of soils; - pollution of soils and crops with heavy metals, etc.

\section{Fig. 3. Scheme of the evolution of irrigated soils}

In order to improve the environmental safety of irrigated agricultural land use on the basis of the USEMS of irrigated land, scenarios of ecologically oriented land use systems in the irrigation zone should be developed and scientifically proved, namely: the use of irrigated land for the cultivation of environmentally safe products; the use of irrigated land in generally accepted regional systems of irrigated agriculture; exclusion of land from irrigation by conservation of separate arrays of irrigated lands that are in degraded condition.

The organizational and economic mechanism for the implementation of environmental monitoring of agricultural land in the zone of irrigation is conducted with the help of land policy instruments: norms, standards, orders, recommendations and instructions. 
One of the measures that will ensure the introduction of ecologically-oriented land-use systems based on environmental monitoring in the conditions of irrigation, is a separate allocation of conservation-exclusion from agricultural circulation for a certain term to implement measures in restoration of their fertility. Exclusion of irrigated land has to be performed in accordance with the requirements presented in the Figure 4.

\section{Conditions for the exclusion of land from irrigation}

\begin{tabular}{|c|c|}
\hline Inventory of irrigated lands & \multirow{2}{*}{$\begin{array}{l}\text { Exclusion from irrigation } \\
\text { of the lands with waters } \\
\text { of III class } \\
\text { (not suitable for irrigation) }\end{array}$} \\
\hline $\begin{array}{l}\text { Poor technical level } \\
\text { of irrigation systems }\end{array}$ & \\
\hline $\begin{array}{l}\text { Temporary exclusion of lands } \\
\text { from irrigation with irrigation } \\
\text { waters of II class (limited } \\
\text { suitable for irrigation) without } \\
\text { the application of complex of } \\
\text { land reclamation measures }\end{array}$ & $\begin{array}{l}\text { Selection of salt- and alkaline } \\
\text { resistant crops adapted } \\
\text { to the agro-ecological } \\
\text { conditions of irrigated lands }\end{array}$ \\
\hline $\begin{array}{r}\text { Conservation of in } \\
\text { in crisis ag }\end{array}$ & $\begin{array}{l}\text { al irrigated lands } \\
\text { ironment }\end{array}$ \\
\hline
\end{tabular}

\section{Fig. 4. Conditions for the exclusion of land from irrigation}

Low-productive, erosion-hazardous and technogenically polluted soils are to be the first to be excluded from agricultural circulation. Conservation of land is carried out by padding or afforestation. Afforestation is one of the efficient measures to improve the ecological stability of the land, which contributes to the restoration of their natural condition.

Due to the growing demand for food in the international market, the territory of Kherson region requires strong controls on the use of land resources. In recent years, a large number of unsolved problems have been accumulated in this field that require to be responded at once: the highest 
plowed land area in Ukraine of 90.4\%; unproductive lands, which could be used for afforestation, were shared; there is no efficient system of consulting for agricultural producers as for the management of agricultural land; there are no tools to support the infrastructure for maintaining soil fertility: irrigation systems, forest belts, inland roads.

In order to improve the land use system, it is necessary to exclude from the intensive cultivation the most degraded and low-productive lands, to provide through the introduction of resource-saving agrotechnologies non-deficient balance of humus and balanced phosphorus content, to stabilize the increase in the areas of saline and alkaline soils.

Schemes for the conservation of degraded and low-productive lands have been developed for each district of Kherson region (Table 5).

It is expected that the conservation and enhancement of degraded and dangerously contaminated lands will contribute to the improvement of the productivity and environmental stability of agricultural landscapes, sustainable land use, improvement of the ecological economic efficiency of agriculture and living conditions of the population.

As the world and domestic experience of irrigation testify, the task of preservation and extended reproduction of soil fertility, in which processes such as salinization, sedimentation, alkalization, compaction, deconstruction, cohesion, crust formation, decalcification, dehumification, impoverishment, contamination, could be solved only with the help of controlled agricultural influences, among which the system of agromeliorative measures occupies the leading place. The list and content of the means of influence on soils depend, firstly, on the degree of their cultivation and degradation; secondly, on the quality of irrigation water and, thirdly, on the ecological agromeliorative conditions of the irrigated lands.

The zones of primary application of the measures should be soils with unsatisfactory (crisis) ecological agromeliorative condition, on which negative processes have reached a strong stage of development. The complex of existing agromeliorative measures in Ukraine, which is the result of many years of the developments of a number of research and project-technological institutions, can minimize the negative impact of irrigation on soils when the irrigation waters of 2-3rd classes are used, but it cannot completely stop soil degradation processes. 
Lands of Kherson region subjected to conservation, ha

\begin{tabular}{|c|c|c|c|c|c|c|c|c|}
\hline \multirow[b]{3}{*}{$\begin{array}{c}\text { The names of } \\
\text { districts }\end{array}$} & \multicolumn{8}{|c|}{ Lands subjected to conservation } \\
\hline & \multirow[b]{2}{*}{ total } & \multicolumn{2}{|c|}{ among them } & \multicolumn{5}{|c|}{ including } \\
\hline & & 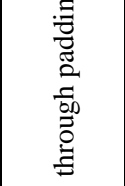 & 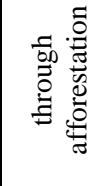 & 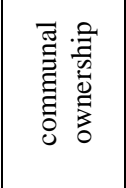 & $\begin{array}{l}\vec{D} \\
\stackrel{0}{0} \\
0 \\
0\end{array}$ & 总 & 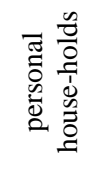 & : \\
\hline Beryslav & 3952.6 & 3952.6 & - & 2066.5 & 492.6 & 550.7 & - & 842.8 \\
\hline Bilozerka & 201.0 & 201.0 & - & - & - & - & - & - \\
\hline $\begin{array}{l}\text { Velyka } \\
\text { Lepetykha }\end{array}$ & 4165.3 & 4165.3 & - & 2882.5 & 523.9 & 526.0 & 232.9 & - \\
\hline $\begin{array}{l}\text { Velyka } \\
\text { Oleksand- } \\
\text { rivka }\end{array}$ & 6186.2 & 5545.3 & 640.9 & 3762.7 & 1006.7 & 938.6 & 330.6 & 147.6 \\
\hline $\begin{array}{l}\text { Verkhnii } \\
\text { Rohachyk }\end{array}$ & 5085.0 & 5085.0 & - & 3185.6 & 241.5 & 824.1 & 11.3 & 822.5 \\
\hline Vysokopillia & 4835.7 & 4835.7 & - & 3577.6 & 821.6 & 180.5 & - & 256.0 \\
\hline Henichesk & 11001.4 & 11001.4 & - & 7759.4 & 2014.1 & 657.6 & 200.1 & 370.2 \\
\hline Hola Prystan & 4492.6 & 3670.0 & 822.6 & - & - & - & - & - \\
\hline Hornostaivka & 3271.14 & 2714.1 & 557.06 & - & - & - & - & - \\
\hline Ivanivka & 5500.7 & 5267.9 & 232.8 & 4067.1 & 849.2 & 422.9 & 34.00 & 127.5 \\
\hline Kalanchak & 3948.1 & 3948.1 & - & 2828.7 & 512.4 & - & 14.4 & 592.6 \\
\hline Kakhovka & 1930.06 & \begin{tabular}{|l|}
1930.06 \\
\end{tabular} & - & 1451.84 & 478.22 & - & - & - \\
\hline $\begin{array}{l}\text { Nyzhni } \\
\text { Sirohozy } \\
\end{array}$ & 1934.3 & 1922.3 & 12.0 & 1590.1 & 81.6 & 137.7 & 62.4 & 62.5 \\
\hline $\begin{array}{l}\text { Novo- } \\
\text { vorontsovka }\end{array}$ & 3347.5 & 3347.5 & - & 1322.3 & 635.3 & 778.7 & - & 611.2 \\
\hline Novotroitsk & 5804.2 & 5804.2 & - & 3801.5 & 597.4 & 551.8 & - & 853.5 \\
\hline Oleshshia & 3063.0 & 1022.3 & 2040.7 & - & - & - & - & - \\
\hline Skadovsk & 2581.2 & 2581.2 & - & 1526.1 & 234.6 & 574.3 & 246.2 & - \\
\hline Chaplynka & 3651.2 & 3651.2 & - & 676.5 & 385.1 & 2504.9 & 35.8 & 48.9 \\
\hline Total & 74951.2 & 70645.14 & 4306.06 & 38908.34 & 8874.22 & 8510.1 & 1105.3 & 4672.8 \\
\hline
\end{tabular}

The main components of such a complex are: the transfer of irrigated agriculture to landscape-adaptive environmentally friendly compensatory systems of agriculture; introduction of a differentiated resource-saving fertilization system; renewal of works on chemical melioration of irrigated soils and irrigation waters; planning of crop irrigation regimes and methods based on compensatory and adaptive principles; exclusion of lands from irrigation in accordance with 
scientifically based principles and regulations; detoxification of contaminated soils; use of modern models of land reclamation management; organization and maintenance of ecological and ameliorative monitoring of irrigated lands.

\section{CONCLUSIONS}

1. In the conditions of constant use of water resources under the limited reserves, a scientifically substantiated system of water economy management and irrigated agriculture, which would ensure optimal distribution of water resources by natural geographical zones and industries, reproduction, protection, complex water use, rational system of water economy complex management, is required.

2. One of the most important aspects in the field of environmental safety of the use of irrigated land is the formation of an institutional environment - a set of system components that provide environmental safety.

3. The main components in the system of institutional support of balanced use of land and water resources in agricultural activities on irrigated lands are: development of institutions of state regulation of the economy in the direction of use of the whole set of forms and methods for land optimization and water use in agricultural formations; taking into account the impact of informal institutions in the use of land and water resources in the process of agricultural policy implementation; optimization of agricultural land use, taking into account the environmental constraints established by existing institutions.

4. The task of preservation and renewal of the fertility of soils, in which degradation processes have developed, can be solved by the means of a system of agromeliorative measures, the main components of which are: the transfer of irrigated agriculture to landscape-adaptive ecologically safe compensatory systems of agriculture; introduction of a differentiated resource-saving fertilization system; renewal of works on chemical melioration of irrigated soils and irrigation waters; planning of crop irrigation regimes and methods based on compensatory and adaptive principles; exclusion of lands from irrigation in accordance with scientifically substantiated principles and regulations; use of modern models of land reclamation management; organization and maintenance of ecological and ameliorative monitoring of irrigated lands. 


\section{SUMMARY}

Agrarian production on irrigated lands anticipates the use of environmentally unsafe substances, irrigation machinery and mechanisms used in the production process and has a certain negative impact on soil, water resources and human health. The article defines the level of ecological safety of agricultural enterprises of Kherson region, which conduct their economic activity on the irrigated lands. The analysis shows that $56 \%$ of the surveyed enterprises have a sustainable level of environmental safety and do not pose a threat to the environment and human, 29 - belong to the unsatisfactory level, 14 - to the crisis, and $1 \%$ are on the critical level. Taking into account existing forms of manifestation of threats to ecological safety, the list of indicators by the criteria and constituent elements of ecological safety in the field of irrigated agriculture is determined. Different scenarios of ecologically oriented land-use systems are presented to evaluate the further efficient use of the irrigated lands, taking into account the ecological conditions of these lands. It is proved that in order to improve the land-use system, the most degraded and lowproductive lands should be excluded from intensive cultivation and through the use of modern resource-saving agrotechnologies a nondeficient humus balance and balanced content of phosphorus have to be provided, the increase of the areas of saline and alkaline soils has to be stabilized.

\section{REFERENCES}

1. Закон України "Про охорону навколишнього природного середовища" [Електронний ресурс]. Режим доступу: http://zakon.rada.gov.ua

2. Качинський А. Б. Екологічна безпека України: системний аналіз перспектив покращення : монографія. К.: НІСД, 2001. 311 с.

3. Карпіщенко О. I., Ксенофонтова М. М. Агроекосистеми: проблеми стійкого розвитку : монографія. Суми: ВАТ “Сумська обласна типографія вид-во “Козацький вал”, 2004. 185 с.

4. Косякова И. В. Организационно-экономические основы экологической деятельности промышленных предприятий : монография. М.: Компания Спутник+, 2006. 316 с.

5. Шевчук В. Я., Саталкін Ю. М., Білявський Г. О. та ін. Екологічне управління : підручник. К.: Либідь, 2004. 432 с. 
6. Фирсов И. В. Методологические основы практического управления в системе обеспечения экономической безопасности. Экономика и предпринимательство. 2014. № 1. Ч. 2(42-2). С. 123-126.

7. Реймерс Н. Ф. Экология (теория, законы, правила, принципы и гипотезы). М., 1994. С. 297-316.

8. Дегодюк Е. Г., Дегодюк С. Е. Еколого-техногенна безпека України : монографія. К.: ЕКМО, 2006. 306 с.

9. Фурдичко О. I. Агроекологія : монографія. К.: Аграрна наука, 2014. 400 c.

10. Муравых А. И. Теоретические основы управления экологической безопасностью : монография. М.: КОМЭК, 2008. 296 с.

11. Чудовська В. А. Інституційне забезпечення органічного виробництва в сільському господарстві / Матеріали доп. міжнар. наук.-практ. конф. "Економічні проблеми сталого розвитку" (м. Суми, 3-5 квітня 2012 р.). Суми: СумДУ, 2012. Т. 1. С. 190-191.

12. Ромащенко М. І., Балюк С. А. Зрошення земель в Україні. Стан та шляхи поліпшення. К.: Світ, 2000. 114 с.

13. Про внесення мінеральних, органічних добрив, гіпсування та вапнування грунтів під урожай 2010-2017 року в сільськогосподарських підприємствах Херсонської області: Статистичний бюлетень / Відп. за випуск Побрус С. В. Херсон: Головне управління статистики у Херсонській області, 2019. 48 с.

14. Закон України "Про меліорацію земель" / Відомості Верховної ради України. 2000. № 11. С. 90.

15. Індикатори стану екологічної безпеки держави: [Електронний ресурс] / Аналітична записка. Національний інститут стратегічних досліджень. Режим доступу: http://www.niss.gov.ua/articles/993/

\section{Information about the author:} Dymov O. M.,

Candidate (Ph.D.) of Agricultural Sciences, Senior Researcher, Head of the Laboratory of Economics, Institute of Irrigated Agriculture of the National Academy of Agrarian Sciences of Ukraine Kherson, Naddnipryanske, 73483, Ukraine 